\title{
CLASSICAL PRAGMATISM, POSTMODERNISM, AND NEOPRAGMATISM
}

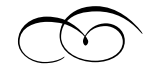

or those who are interested in coming to grips with the problems
and prospects of our increasingly technological culture, classical Pragmatism appears to offer significant advantages over some currently popular versions of neopragmatism. ${ }^{1}$ Whereas the experimentalist version of Pragmatism advanced by Dewey honored the distinct roles that the arts and the technosciences can play in, for example, social reconstruction, the neopragmatism of Rorty tends to alternate between blurring that distinction, on the one hand, and depicting technoscience as just one more of the literary arts, on the other. Moreover, whereas Dewey's version of Pragmatism emphasizes the objectivity of results achieved through application of what he termed "the denotative method," some versions of neopragmatism insist on the relativism of personal and cultural preferences. They thus attempt to displace classical Pragmatism's thick program of active experimental analysis and reconstruction with thinner projects that present hoping and coping as the best available outcome for progress. 
There are a number of important differences between Dewey's classic version of Pragmatism, which he on various occasions termed "Instrumentalism" and "experimentalism," and more recent versions of Pragmatism collectively known as neopragmatism. Among those who have identified themselves (and been identified) with this recent version of Pragmatism are what might be termed "legal Pragmatists," such as Richard Posner, "literary Pragmatists," such as Stanley Fish, and others as well. Within the field of philosophy, however, neopragmatism has received its most eloquent expression in the work of Richard Rorty.

It is by now clear that Rorty has exerted an enormous influence on late-twentieth- and early-twenty-first-century philosophy. Two facts about his work stand out in high relief. First, his efforts have played a crucial role in the revival of interest in the classical Pragmatism of Peirce, James, Dewey, and George Herbert Mead. Rorty's 1979 presidential address to the Eastern Division of the American Philosophical Association, to which he gave the title "Pragmatism, Relativism, and Irrationalism," was at the time perceived as a dramatic intervention into the ordinary business of mainstream Anglo-American philosophy. ${ }^{2}$ Today it can only be viewed as a watershed event, or better, a dredging operation that cleared away obstructions that had prevented mainstream philosophy from addressing what Dewey would today probably call the problems of men and women. The revival of American Pragmatism would probably have occurred in any event, since a new generation of philosophers was beginning to turn its attention to matters commonly termed "applied." But it can be said with confidence that Rorty's effort cleared the way for the current situation.

The second prominent fact is that Rorty constructs a novel type of Pragmatism that weaves together various strands of classical Pragmatism with themes from contemporary (primarily French) postmodernist philosophy. ${ }^{3}$

Rorty has not been shy about acknowledging this situation; he has in fact written extensively about the relations between classical Pragmatism and postmodernist thought. In general, it seems fair to say that he thinks that classical Pragmatism not only anticipated some of 
the problems that continue to vex postmodernist thought, but offered viable solutions for them as well. In 1982, for example, he wrote, "James and Dewey were not only waiting at the end of the dialectical road which analytic philosophy traveled, but are waiting at the end of the road which, for example, Foucault and Deleuze are currently traveling." " Elaborating on this theme later in the same book, he added, "We should see Dewey as having already gone the route Foucault is traveling, and as having arrived at the point Foucault is still trying to reach-the point at which we can make philosophical and historical ('genealogical') reflection useful to those, in Foucault's phrase, 'whose fight is located in the fine meshes of the webs of power.' "'

To the attentive reader, these passages might provoke the following question: what is there of postmodernism in Rorty's thought that is both worthwhile and that cannot be found within the classical Pragmatism of James and Dewey? A proper answer to this question will require a brief detour through some of the main points of modernist and postmodern thought.

Historian James Livingston provides a particularly helpful set of guideposts in this regard, so I will quote him at length. In Livingston's view, the Pragmatism of James and Dewey sanctions a personality that "seems both sensible and scandalous, both inevitable and impossible."' In Livingston's characterization, the practitioners of classical Pragmatism are already postmodernists in the sense that they

do not believe that thoughts and things inhabit different ontological orders: they do not acknowledge an external or natural realm of objects, of things-in-themselves, which is ultimately impervious to, or fundamentally different than, thought or mind or consciousness. Accordingly they escape the structure of meanings built around the modern subjectivity, which presupposes the self's separation or cognitive distance from this reified realm of objects. More to the point, these theoreticians are not necessarily trapped between the epistemological extremes enabled by modern subjectivity - that is, between romanticism, which typically glorifies the "organic" or "subjective" inner self as against the "mechanical" or "objective" circumstances that constitute outward 
existence; and positivism, which typically celebrates the increasing density of that external, thing like realm of objects and the evidence of progress toward the species' mastery of nature. ${ }^{7}$

Why does this situation appear to some as both "sensible and scandalous," both "inevitable and impossible"? Simply this: the classical Pragmatists were able to reclaim the continuities between mind and matter, facts and values, and, perhaps even more importantly, between past and present that had been disrupted in modernist thought, even while retaining and advancing a positive view of the technosciences. The classical Pragmatists argued that future possibilities can be assessed in the light of past events in ways that go beyond mere critique of, or resistance to, both choices made in the past and conditions currently in place. Classical Pragmatism thus introduces into the course of human events a type of thick social behaviorist morality-and thus a type of thick social and political engagement that is based on experimental methods, that rejects the traditional split between facts and values, and that is therefore unavailable to those working within the modernist model.

Although classical Pragmatism may legitimately be termed "postmodernism,"8 then, it does not, as do some of the programs currently designated by that name, sanction radical forms of relativism such as those that have been termed "judgmental" or "cognitive" relativism. From the standpoint of classical Pragmatism, modernist models got locked up in a positivist outlook that apotheosized attempts by physical scientists and others to provide a philosophical basis for what they were doing. As a radical form of positivism, therefore, modernism consequently treated much of the cultural and moral life in reductive fashion either as straight-line instrumentalist or transcendentally based, or else as simply noncognitive. On the other side, from the standpoint of the classical Pragmatist, the accounts of the postmodernist thinkers have inverted this model, treating the proven methods of the physical sciences as if they were expressions of an infinitely selfreflexive nexus of literary descriptions and redescriptions which are tantamount to interminable discursive flights that do not offer the possibility of firm behavioral, referential perches. 
On this postmodernist model cultural and moral life also is relativized and fragmented, since, as one postmodernist writer has put the matter, "The truth value of all judgments is relative to some particular standpoint (otherwise variously referred to as a theoretical framework, conceptual scheme, perspective, or point of view) [and] no standpoint is uniquely or supremely privileged over all others." ${ }^{\prime}$

In one sense, of course, this statement is trivially true. Putative absolutes are all relative to something or other. In a more important sense, however, if it were nontrivially true then it would be toothless because applicable only relative to the particular standpoint, theoretical framework, conceptual scheme, perspective, or point of view of its author. And in a still more important sense, if we accept the types of experimental naturalism and social behaviorism advanced by the classical Pragmatists, the statement is simply false. For one thing, it raises relativism to the level of an absolute. For another, its falsity can be demonstrated by various counterexamples such as can be found in the natural sciences. Among these are ones used by Dewey himself, for example, that pure tin melts at $232^{\circ} \mathrm{C}$ at 1 standard atmosphere. This is true in Dewey's sense of "warranted assertibility" and, save the fallibilist component built into the notion of warranted assertibility, it is not subject to endless redescription. Moreover, it is true whether we perform the experiment in Kansas City, Köln, Kandahar, or Paris.

Early on, then, during the last decades of the nineteenth and early decades of the twentieth centuries, long before the term "postmodern" had been coined, classical Pragmatism was by definition postmodernist. On one count it was postmodernist because it repudiated the various forms of dualism that had vitiated modernist thought. One need only revisit Peirce's essays "The Fixation of Belief" and "How to Make Our Ideas Clear," published in 1877 and 1878 respectively, to begin to get a sense of just how savage the classical Pragmatist critique of Cartesian modernism was.

In the place of modernism, classical Pragmatism advanced an account of human situatedness and engagement that stressed the objectivity that comes from responsibility for ongoing experimental involvement in the facts of a case. Perhaps even more important, 
however, classical Pragmatism stressed the real possibility that behavior can be changed, and that behavioral change can be expressed in both individual and institutional habits. To put this matter somewhat differently, classical Pragmatism is postmodern in the following senses. It rejects Cartesian and other types of attempts to provide ultimate foundations for knowledge claims, opting instead for a view of knowledge-getting that involves the construction and reconstruction of temporally differentiated platforms of action from which to construct further platforms, and so on indefinitely.

It rejects the spectator theory of knowledge, according to which true knowledge is constituted by an accurate internal representation of an external fact, electing instead a perspectival view of knowledgegetting that stresses themes currently associated with attempts to extend democratic participation and appreciation of cultural differences, or what Dewey termed "associated living."

It rejects the view that the sources of knowledge or the norms thereof are derived from locations that are outside of experience itself. In other words, both the transcendent accounts of supernaturalist theologies and various forms of Platonism, as well as Kantian accounts of knowledge-getting that depend upon a transcendental ego, are rejected in favor of an Instrumentalist/experimentalist account according to which norms, just as other types of tools, are developed in the course of experience as problems are encountered, articulated, and resolved.

It rejects the idea that human knowing can achieve absolute certainty, opting instead for versions of fallibilism according to which working hypotheses, rules of thumb, and even well proven instruments are open to revision under appropriate circumstances. And it rejects the possibility of the grand narrative, opting instead for situated, contexted attempts at piecemeal meliorism.

The central problems and issues of modern thought are thus thoroughly recast within the texts of classical Pragmatism. What Dewey termed "the quest for certainty," based ultimately on an obsession with skepticism that seems to have been the leitmotif of modernist thought, is rejected as unproductive. Its place is taken by confidence 
that the methods of problem solving-methods that have enjoyed their most spectacular successes in the natural sciences-constitute the best available means for knowledge-getting.

Modernist subjectivity is also recast. The self of classical Pragmatism is no longer isolated as a self-contained thinking entity-such as a transcendental ego-over against an external world of objects and (perhaps also) other thinking entities. The self of classical Pragmatism is instead an organic complex of impulses, abilities, habits, and behaviors that is deeply rooted in the natural history of the human organism and dependent on complex social environments for its growth and development. The self of classical Pragmatism is, nevertheless, not so decentered as to be elusive, as some postmodernist writers would have it.

In all this I have attempted to indicate how classical Pragmatism, from the 1870 s onward, rejected the central claims of modern philosophy. This was not fruitless resistance, the shaking of a fist in the face of a dominant philosophical system. Classical Pragmatism replaced the modernist program with an alternative that was positive, detailed, and consistent.

If classical Pragmatism is postmodernist by definition, and if it is truly characterized in the manner in which I have indicated in the preceding paragraphs, then it has a prior claim to the name "postmodernism." But what then of the later postmodernism, the one that for the sake of clarity I will call "official postmodernism"? What of that official (primarily French) postmodernism that Rorty has woven together with strands of classical Pragmatism in order to produce his neopragmatism? I shall consider this question under two headings, even though there are others that are relevant to the current discussion.

First, Rorty's neopragmatism shares with official postmodernism what is arguably an inversion of the modernist depiction of the relation between the sciences and the arts. Modernism, with its preference for the quantitative over the qualitative, its preference for qualities that it regarded as primary over those it regarded as secondary, tended as a consequence to treat the arts as inferior or subservient to the sciences. This phenomenon was apparent as late as the 
middle of the twentieth century, which witnessed the last gasps of the program of logical positivism.

But now the modernist-positivist program appears to have been turned on its head by official postmodernism. This is perhaps nowhere more apparent than in the famous hoax perpetrated by physicist Alan Sokal. In 1996 Sokal submitted an essay to the influential journal of cultural studies Social Text, in which he argued that "physical reality" was nothing more than a social construct and that the objects of the natural sciences, including mathematics, are culturally determined. His paper, written as a parody of the texts of official postmodernism was accepted and published. When Sokal revealed his hoax, there was great indignation on the part of the journal's editors and the other targets of his spoof. Sokal responded by publishing a book in which he expanded his attempts to unmask what he took to be the faux science that he had found in the texts of some of the most influential proponents of official postmodernism. ${ }^{10}$ Jacques Lacan, Julia Kristeva, Luce Irigaray, Gilles Deleuze, and Jean Baudrillard were among his targets. One reviewer attempted to assess the damage: "But what is the crime here? At worst these French theorists are bluffeurs. They do not hate science; they love it too well and try to wrap themselves in its mantle." 11

I would put matters differently. After examining the texts that Sokal presents in support of his case, I would suggest that they illustrate a mirror image or inversion of positivism, namely a romantic subsumption of technoscience to the subjective side of the arts, an attempt to involve or encase the quantitative, denotative features of the technosciences within a cocoon of self-reflexive, qualitative discourse. In these texts, the technosciences are at first deracinated and then called upon to serve the demands of high literary style.

To be fair, it should be noted that Rorty himself has not gone to the extremes that one finds in some of the texts of official postmodernism. But I believe that he has nevertheless to a considerable extent followed their lead. He interprets Dewey, for example, as having attempted to "rub out" the distinctions between the arts, technoscience, and philosophy, and to substitute for them a "vague and 
uncontroversial notion of intelligence." 12 But, as I have noted elsewhere, Rorty also seems to think that the technosciences are receding into the background and that it is the poet who is in ascendency. As for philosophy, he has suggested that it would be better to "avoid thinking of philosophy as a 'discipline' with 'core problems' or with a social function." 13 The poet is, after all, the "one who makes things new." 14

But of course Dewey did not attempt to "rub out' the distinctions between the arts and the sciences. On that matter he was quite clear. In this sense classical Pragmatism subscribes neither to the positivist model or the standard postmodernist inversion of it. For Dewey, it is the business of the arts to express meanings, and the business of the sciences to state meanings. What this means in concrete terms is that Dewey realized that the history of human problem-solving has developed at least two complementary types of approaches to the resolution of situations that are unsettled. Rather than privilege either the arts or the sciences, Dewey argued that the methods that they can bring to situations that require resolution are not only different from one another, and not only cooperative, but applicable in different ratios depending on the nature of the required resolution. Where the overt statements of technoscience are either censored or unheeded, for example, it is often possible for the arts to motivate social change. One current example of this situation is the Iranian cinema, in which social stigmas attached to women as a group are explored in ways that are calculated to provoke the types of debate that can lead to reform. Of course the opposite situation can also obtain, that is, when the arts are censored or unheeded and the natural or social sciences are employed as vehicles for the solution of problematic situations. Examples abound, and include the quantitative studies regularly published by Andrew Hacker that deal with the feminization of poverty in the United States or the research that went into the identification of the causes of AIDS. Ideally, of course, the arts and the sciences do their work as partners.

Second, with respect to the role of philosophy as tool for social engagement and change, there is also a less than ideal match between 
Dewey's classical Pragmatism and Rorty's neopragmatism. Apart from Rorty's general suggestions in Achieving Our Country concerning ways in which liberals can and should be more patriotic, less enamored of theoretical excesses, and more imaginatively melioristic in their roles as nonspecialist private citizens, his work exhibits little that resembles Dewey's commitment to experimental work undertaken by philosophers qua philosophers.

This situation is especially evident when it comes to the respective accounts of the two philosophers regarding the role of discourse in social and political amelioration. Whereas Dewey considered discourse an important phase within the complex of methods he termed "denotative," Rorty's notion of discourse is more akin to that of Habermas: to the extent that discussion of the experimental dimension of Dewey's denotative method is there at all, it is buried deeply inside discussions of discourse and communicative action. ${ }^{15}$

This general assessment should not, however, be taken as an attempt to obscure the fact that Rorty's views concerning social and political matters seem to have changed over the course of the last couple of decades.

Responding to his work as it stood circa 1985, for example, Ralph Sleeper was particularly critical of Rorty's notion of an "ungrounded social hope."

We are left, [Rorty] tells us, with "ungrounded social hope" and a philosophy that can provide us with nothing more than occasional illumination to dispel the gathering gloom. Philosophy, according to Rorty, is to give "edification," and there doesn't seem to be anything very edifying in Rorty's attenuation of philosophy's function to the point where it becomes indistinguishable from that of literary criticism. What rankles is Rorty's insouciant reductionism. Pragmatism—at least Dewey's sort—had seemed to offer us more than that. It had seemed to be teaching us how to transform the culture that is decaying around us, rather than just how to "cope" with its collapse."16

Rorty's work circa 1990 led to my own suggestion, ${ }^{17}$ that the program of his liberal ironist resembles nothing so much as a kind of 
secular Calvinism. The liberal ironist, like the Calvinist, is skeptical about the efficacy of tool use; philosophy, it is said, cannot provide much in the way of help concerning how we are to orient ourselves toward our lifeworld. For both the liberal ironist and the Calvinist, the emphasis is upon individual regeneration, which might then, provided conditions are favorable, perhaps find some means of expression in the realm of the social.

Of course this analogy is far from perfect: whereas the Calvinist relies on the grace of God for redemption, the liberal ironist relies on the muse, friends, and books to stimulate his or her imagination. The liberal ironist hopes to get from friends and books the kind of literary redescriptions that will nourish the flickering flame of ungrounded hope. Moreover, it should be recalled that whereas Calvinism posited a self (read soul) that was so very palpable as to be all but substantial, Rorty's decentered self is chameleon-like by comparison. At certain times it seems to resemble nothing so much as the fractured self of official postmodernism or the centerless Humean self. ${ }^{18}$ At other times, however, it appears in the guise of the more solid, active, integrating self that Dewey presents in Human Nature and Conduct. It is there, for example, that Dewey writes of a "self [that] gets solidity and form through an appropriation of things which identifies them with whatever we call myself" (MW 14.82).

More recently, and most prominently in Achieving Our Country, in several essays published during 1996 and 1997, and in the responses to his critics in Rorty and Pragmatism, ${ }^{19}$ the social and political have taken on an expanded dimension in Rorty's work. In his essay "Globalization, the Politics of Identity and Social Hope," for example, he takes a position that seems to echo that of Habermas, namely, that nothing "can take precedence over the result of agreement freely reached by members of a democratic community." 20

Even more to the point of my argument in this essay, Rorty attributes this view to Dewey. For both Habermas and Dewey, he suggests, "the reason this kind of philosophy is relevant to politics is simply that it encourages people to have a self-image in which their real or imagined citizenship in a democratic republic is central. . . . 
This kind of philosophy, so to speak, clears philosophy out of the way in order to let the imagination play upon the possibilities of a utopian future." 21

Rorty's preference for a social and political program that clears philosophy out of the way has also been noted by Steven Shapin, who reads him as suggesting that "philosophers should either shut up shop or take themselves off to the humbler departments of sociology, history and psychology: 'Philosophy does not make much difference to our practices, and should not be allowed to do so. . . . For most purposes, whether we have any philosophers around or not doesn't really matter.' "'22

Rorty may describe himself as a "follower" of Dewey in these matters, but his Dewey is not one that I am able to recognize. As I read him, Dewey thought that philosophy and philosophers still have important work to do, and that most of that work can be articulated in terms of projects that are social and political. As I read him, Dewey thought that the denotative method was at the heart of philosophical inquiry. Here is Dewey in 1925, in the first chapter of Experience and Nature.

The empirical method points out when and where and how things of a designated description have been arrived at. It places before others a map of the road that has been travelled; they may accordingly, if they will, re-travel the road to inspect the landscape for themselves. Thus the findings of one may be rectified and extended by the findings of others, with as much assurance as is humanly possible of confirmation, extension and rectification. The adoption of empirical, or denotative, method would thus procure for philosophic reflection something of that cooperative tendency toward consensus which marks inquiry in the natural sciences. The scientific investigator convinces others not by the plausibility of his definitions and the cogency of his dialectic, but by placing before them the specified course of experiences of searchings, doings and findings in consequence of which certain things have been found. His appeal is for others to traverse a similar course, so as to see how what they find corresponds with his report. (LW 1.389-90) 
This passage reveals several aspects of Dewey's thought that are both important and at variance with Rorty's neopragmatism. For one thing, contrary to Rorty and Habermas, Dewey refuses to characterize definitions and dialectic (discourse) as primary or even central, that is, as practices within which experimentation is present but somehow remains submerged. Dewey's account turns matters the other way around. Discourse-definition and dialectic — is a phase of a larger program of experimental or inquirential activity. Since they are both postmodernist thinkers, of course, both Dewey and Rorty think that it is high time that we jettisoned the bulk of classical, medieval, and modernist metaphysics. But unlike Rorty, Dewey thinks it is part of the work of philosophers to determine how such idols of the tribe can be disposed of, and what kinds of things will take their place. And since each generation has its own metaphysical blind spots, philosophy and philosophers will still have a lot of work to do that does not fall within the scope of disciplines such as sociology, history, psychology, or even comparative literature.

In all this it is not that Rorty's goals are not admirable, for indeed they are. It is just that in this respect, at least, his neopragmatism seems somewhat timid and even nebulous when compared to the robust program of experimental reconstruction advanced as a part of Dewey's classical Pragmatism.

Dewey's commitment to, and Rorty's insouciance for, experimentalism is a matter that I have discussed elsewhere. ${ }^{23}$ It is also a matter that James Gouinlock has taken up in his excellent essay "What is the Legacy of Instrumentalism?"24 In my view, Gouinlock hits his mark dead center when he reads Dewey as arguing that the methods of science and the methods of democracy are not separate. Instead, he writes, "the norms of science are incorporated into those of democracy." ${ }_{25}$ Moreover, it is the "responsibilities of schools to provide an environment in which scientific-democratic virtues will be acquired as an organic part of the learning process." ${ }^{26}$ In short, Gouinlock argues that Dewey's scientific-democratic commitments offer much more than ungrounded social hope. In his reply to Gouinlock, Rorty 
admits that he finds the notion of a scientific method "pretty useless." ${ }^{27}$ Further, the term "method" "was not a fortunate choice. It promised more than he [Dewey] could offer-something positive, rather than the merely negative admonition not to get trapped in the past." 28 Again, "Granted that Dewey never stopped talking about 'scientific method,' I submit that he never had anything very useful to say about it." 29

Even in the face of Gouinlock's direct challenge, then, Rorty maintains a stance toward the denotative or scientific method that is best termed vague. Unless one is dealing with Burkean conservatives or religious fundamentalists, he writes, the method is just "too noncontroversial to make a fuss about." Moreover, he doesn't see much difference between the method of a priori reasoning and the method of science except that "the former discourages, and the latter encourages, bold and imaginative speculation." ${ }^{30}$

Rorty's position on these matters hardly matches up with Dewey's version of Pragmatism. In our own time, just as in Dewey's, some of the most heated discussions at school board meetings take place between those who advocate teaching the methods and content of science and those who advocate teaching the methods and content of antiscientific alternatives. Whereas Dewey struggled with proponents of creationism, educators today must struggle with proponents of intelligent design.

Surely such discussions are about more than the merely negative admonition not to get trapped in the past. They are also about the successes of the denotative method in displacing disease, superstition, and bad government. They are about improvements in the methods of organizing communities of scientific research, communities of educational practice, and even communities of mutual therapeutic interests. In all this it is not simply a matter of not getting trapped in the past: it is also a matter of taking what is good from the past and building on it. Dewey's rich account of the denotative method takes into account the evolution of that very method. He correctly notes that it is the only method yet devised that is self-correcting. 
And yet Rorty is correct, if only in a tangential sense, in saying that what Dewey called a method was in fact a whole complex of methods. Dewey recognized this fact, however, and that recognition is evident in his published work. In the final chapters of Experience and Nature, for example, Dewey discussed the ways in which the methods of the arts, sciences, technical disciplines, humanities, jurisprudence, and so on, each have unique yet overlapping bodies of method and content. He also indicated his view that one of the most important functions of philosophy was to act as a liaison officer, rendering the languages of these various disciplines intelligible to one another.

Unlike Rorty, then, Dewey thought that methods matter and that philosophy continues to be relevant. That is one of the big differences between classic Pragmatism and neopragmatism. And that may also be one of the reasons why the Rortian neopragmatist is left with ungrounded social hope. 